\title{
Studi Empiris Government Effectiveness dan Trade Openness terhadap Perdagangan Internasional
}

\author{
Risa Sari Pertiwi' ${ }^{1)}$, Sri Herianingrum²), Muhammad Ubaidillah Al Mustofa ${ }^{3)}$, \\ Mumuh Muhammad ${ }^{4)}$ \\ ${ }^{1}$ Magister Sains Ekonomi Islam, Fakultas Ekonomi dan Bisnis, Universitas Airlangga \\ ${ }^{2,3}$ Departemen Ekonomi Syariah, Fakultas Ekonomi dan Bisnis, Universitas Airlangga \\ ${ }^{4}$ Sosyal Bilimler Enstitusu, Islamic Economics and Finance, Istanbul University, Turkey \\ Email: risa.sari.pertiwi-2018@pasca.unair.ac.id
}

\begin{abstract}
This study aims to examine the impact of macroeconomic factors such as Inflation, Exchange Rates, Total Labor Force, Technology, Worldwide Government and Trade Openness on International Trade in 10 Islamic countries as the main actors of international trade Intra-OKI from 2005 to 2018. Quantitative research This applies the Panel Data Regression method to the Fixed Effect Model. Research analysis techniques use the EViews 10. software program. Empirical results show that inflation and total labor force, government effectiveness and trade openness have a significant positive effect to Intra-OKI international trade. This means that the better the quality of worldwide government and trade openness in a country will increase the country's international trade activities. In addition, exchange rates and technology do not have a significant effect in Intra-OKI international trade.
\end{abstract}

Keyword: International Trade, Government Effectiveness, Trade Openness.

Abstrak: Tujuan penelitian ini untuk menguji dampak faktor makroekonomi seperti Inflasi, Nilai Tukar, Total Angkatan Kerja, Teknologi, faktor Tata Kelola Pemerintah dan Keterbukaan Perdagangan terhadap Perdagangan Internasional di 10 negara Islam sebagai pelaku utama perdagangan internasional Intra-OKI sejak tahun 2005 hingga tahun 2018. Penelitian kuantitatif ini mengaplikasikan metode Regresi Data Panel dengan Model Fixed Effect. Teknik analisis penelitian menggunakan program software EViews 10. Hasil empiris menunjukkan bahwa tingkat inflasi dan total angkatan kerja, efektivitas pemerintah dan keterbukaan perdagangan memiliki pengaruh positif signifikan terhadap perdagangan internasional Intra-OKI. Artinya bahwa semakin baik kualitas tata kelola pemerintah dan keterbukaan perdagangan di suatu negara maka akan meningkatkan aktivitas perdagangan internasional suatu negara. Selain itu, nilai tukar dan teknologi tidak memiliki peranan yang signifikan terhadap perdagangan internasional Intra-OKI.

Kata Kunci: Perdagangan Internasional, Efektivitas Pemerintah, Keterbukaan Perdagangan. 


\section{PENDAHULUAN}

Perdagangan luar negeri menurut (Dumairy, 1999) adalah kegiatan ekonomi hubungan antar negara dari hasil produksi dalam negeri untuk memacu industri dalam negeri dengan cara ekspor dan impor. Tujuan perdagangan internasional untuk meningkatkan kesejahteraan masyarakat, tercapainya keseimbangan neraca pembayaran dan lainnya. Perdagangan internasional memiliki peran penting dalam menghasilkan pertumbuhan ekonomi, lapangan kerja dan pembangunan ekonomi. Namun, banyak negara gagal mendapatkan keuntungan dari perdagangan internasional karena banyaknya tantangan yang memiliki tingkat heterogenitas tinggi dalam hal geografi, ukuran, populasi, dan perkembangan ekonomi.

Negara-negara yang termasuk Anggota Organisasi Kerja Sama Islam (OKI) telah menunjukkan kinerja perdagangan global yang signifikan (Comcec, 2018). Hal ini sebagaimana dalam kutipan ayat dalam QS. Al-Maidah: 2 bahwa adanya perintah untuk saling tolong menolong dalam hal kebaikan (kebajikan dan takwa) dan jangan saling tolong menolong dalam berbuat dosa dan permusuhan. Negara-negara Anggota OKI telah memberikan kontribusi pada peningkatan volume perdagangan global saat terjadi fluktuasi harga komoditas dan dolar AS terhadap mata uang lokal serta situasi geopolitik dan ekonomi negara-negara OKI. Pelaku utama perdagangan luar negeri Negara-negara Anggota OKI pada tahun 2017 adalah Malaysia, Turki, Uni Emirat Arab (UEA), Arab Saudi, Indonesia, Iran, Irak, Qatar, Mesir, dan Kuwait. Perkembangan perdagangan internasional dari total Intra-OKI ekspor dan Intra-OKI impor pada tahun 2018 dapat dilihat pada Gambar 1.

Gambar 1. Pemain Utama Perdagangan Internasional di Intra-OKI Tahun 2018 (Miliar USD)

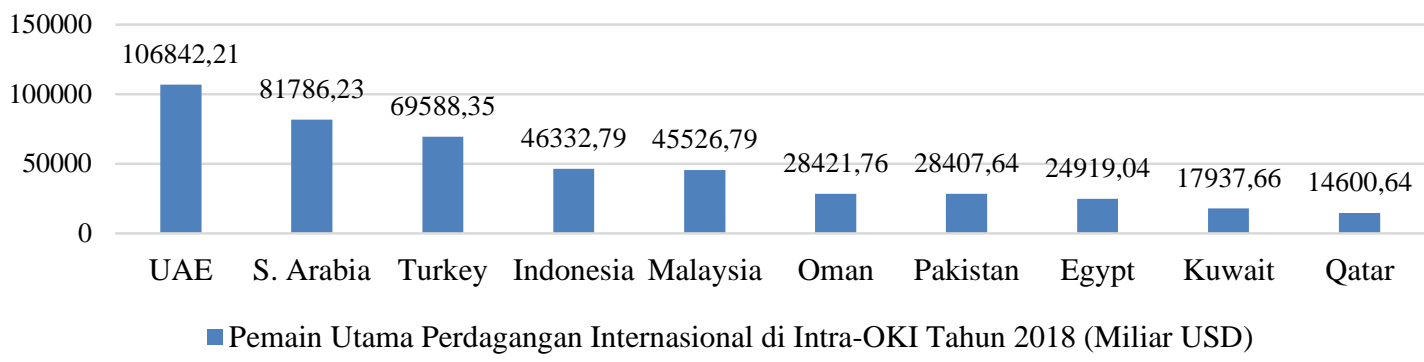

Sumber: (Sesric, 2019)

Berdasarkan Gambar 1. menunjukkan bahwa negara-negara terkemuka dalam perdagangan Intra-OKI pada tahun 2017 antara lain Uni Emirat Arab menempati peringkat pertama dan diikuti oleh Turki, Arab Saudi, Indonesia dan Malaysia. Sepuluh negara teratas menyumbang 73,6 persen dari perdagangan Intra-OKI (Comcec, 2018). Produkproduk utama yang dipasarkan oleh Negara-negara Anggota OKI pada 2017 terdiri dari barang-barang manufaktur lain-lain (28\%), produk makanan (24\%); mesin dan peralatan transportasi (11\%), bahan kimia (11\%) dan bahan baku tidak dapat dimakan (5\%). Hal ini menunjukkan bahwa kebutuhan primer menjadi produk utama kegiatan perdagangan 
internasional Intra-OKI dalam memenuhi kebutuhan masyarakat di suatu negara (Comcec, 2019).

Hasil studi empiris sebelumnya seperti (Octavia dan Wulandari, 2016); (Kang dan Dagli, 2018) yang menganalisis pengaruh variabel makro terhadap perdagangan internasional. Selain itu (Auboin dan Ruta, 2013) berfokus pada hubungan variabel makro ekonomi dari nilai tukar dan perdagangan internasional yang menemukan dampak negative dari nilai tukar terhadap perdagangan internasional. (Madura, 2010) mengatakan bahwa variabel makro ekonomi seperti inflasi, nilai tukar, pendapatan nasional dan kebijakan pemerintah dapat mempengaruhi bisnis ekspor dan impor. Hal ini berarti bahwa ketika tingkat inflasi suatu negara meningkat terhadap negara-negara tempat perdagangannya, maka transaksi berjalannya diperkirakan akan menurun. Konsumen dan perusahaan lokal diharapkan untuk membeli barang-barang asing karena harga lokal yang tinggi, yang mengakibatkan penurunan ekspor negara itu. Fluktuasi dan ketidakpastian dalam tingkat inflasi tidak hanya menciptakan kesulitan dalam ekonomi tetapi juga dalam domain perdagangan eksternal suatu negara.

Beberapa fakta yang memiliki hubungan dengan tata kelola pemerintah antara lain seperti fenomena krisis ekonomi di Amerika Serikat pada tahun 2008 karena permasalahan produk derivatif keuangan subprime mortagage yakni kredit perumahan (Toarna dan Cojanu, 2015). Di sisi lain, Yunani baru-baru ini menderita krisis ekonomi. Hal ini disebabkan karena adanya ketidakseimbangan antara besarnya pengeluaran negara yang disertai dengan kegagalan pemerintah untuk melunasi obligasi negara menjadi penyebab utama terjadinya krisis. Oleh karena itu, fakta-fakta tersebut menjadi salah satu akibat adanya kesalahan tata kelola pemerintah yang suka mengambil hutang untuk membiayai hal-hal yang tidak produktif (Baltas, 2013). Di samping itu, (Majoka et al., 2012) menyebutkan bahwa salah satu kelemahan utama negara yang memiliki mayoritas kaum Muslim yaitu tidak memiliki kemandirian, artinya masih harus bergantung kepada negara lainnya, oleh karena itu diperlukan suatu sistem tata kelola pemerintah yang tepat untuk mengurangi permasalahan sosial ekonomi negara Muslim tersebut. Berdasarkan fenomena permasalahan tersebut, menurut hasil riset (Kayalvizhi dan Thenmozhi, 2018) yang menganalisis 22 negara berkembang menyebutkan bahwa standar tata kelola perusahaan akan berpengaruh terhadap keputusan investasi, meskipun banyak dari standar ini tidak diterapkan secara efektif dan efisien. Namun, lingkungan institusional dalam ekonomi akan memoderasi keputusan investasi.

Selain itu faktor Trade Openness atau keterbukaan perdagangan memiliki peran penting bagi keterbukaan ekonomi dalam mempromosikan pertumbuhan yang cepat dan kemajuan sosial yang berkelanjutan. Secara praktis, liberalisasi perdagangan telah mengakibatkan peningkatan ukuran ekonomi sebagaimana hasil riset (Nath dan Mamun, 2004) menyatakan bahwa keterbukaan perdagangan mendorong investasi dalam ekonomi Bangladesh. Di sisi lain, keterbukaan perdagangan mengukur tingkat perdagangan internasional suatu negara (Pan et al., 2019). Selain itu Trade Openness merupakan faktor penting dari integrasi keuangan internasional di negara-negara GCC dan memiliki hubungan positif signifikan (Alotaibi dan Mishra, 2014). Selain itu (Madanizadeh dan Pilvar, 2019) menyelidiki dampak keterbukaan perdagangan terhadap tingkat partisipasi angkatan kerja. Adapun hasil studi empiris (Chakrabarti, 2018) menemukan bahwa pada tingkat negara, volatilitas makroekonomi cenderung berkorelasi dengan keterbukaan perdagangan. 
Penelitian ini akan mengukur pengaruh Worldwide Governance Indicators (WGI) sebagai data penelitian yang merangkum pandangan tentang kualitas tata kelola pemerintah terhadap aktivitas perdagangan internasional pada negara-negara yang termasuk pelaku utama Intra-OKI. Selain itu adanya keterbukaan perdagangan (Trade Openness) akan memperluas peluang bisnis bagi perusahaan lokal dengan membuka pasar baru, menghilangkan hambatan dan membuatnya lebih mudah pada perdagangan internasional. Oleh karena itu, adanya Worldwide Governance dan Trade Openness yang baik akan memberikan stimulus untuk mendorong pertumbuhan perdagangan internasional pada intra-OKI.

Berbagai studi empiris sebelumnya menemukan hal yang berbeda-beda sehingga terdapat research gap yang kemudian akan diteliti kembali untuk menghasilkan kesimpulan yang baru. Penelitian ini bertujuan untuk menyelidiki variabel makroekonomi, kualitas kelembagaan atau tata kelola negara dan keterbukaan perdagangan terhadap perdagangan internasional Intra-OKI. Studi ini akan mengembangkan penelitian yang dilakukan oleh (Chakrabarti, 2018) yang mempelajari volatilitas makroekonomi yang cenderung berkorelasi dengan keterbukaan perdagangan. Perluasan ini disertai dengan faktor tambahan kualitas kelembagaan atau tata kelola negara (Worldwide Governance) dan keterbukaan perdagangan (Trade Openness) yang akan dianalisis. Hal ini membuat penulis tertarik untuk menganalisa faktor tata kelola negara dan keterbukaan perdagangan secara bersamaan dalam model penelitian terhadap perdagangan internasional Intra-OKI. Tata kelola negara (Worldwide Governance) dan keterbukaan perdagangan (Trade Openness) adalah faktor penting yang harus dipertimbangkan dalam kegiatan perdagangan internasional sebagai keputusan dalam ekspor maupun impor. Implikasi hasil penelitian ini akan memberikan masukan kepada pemerintah dan perusahaan industri barang maupun jasa yakni pihak yang akan mengambil manfaat paling besar dari temuan empiris penelitian ini. Selain itu, penelitian ini diproyeksikan untuk menyoroti peran signifikan tata kelola negara (Worldwide Governance) dan keterbukaan perdagangan (Trade Openness) yang disertai dengan memberikan panduan, wawasan atau pemikiran untuk membantu dalam pembuatan kebijakan mengenai perdagangan internasional intra-OKI.

\section{KAJIAN TEORI}

Perdagangan luar negeri menurut (Dumairy, 1999) adalah kegiatan ekonomi hubungan antar negara dari hasil produksi dalam negeri untuk memacu industri dalam negeri dengan cara ekspor dan impor. Tujuan perdagangan internasional untuk meningkatkan kesejahteraan masyarakat, tercapainya keseimbangan neraca pembayaran dan lainnya. (Madura, 2010) mengatakan bahwa variabel ekonomi makro seperti inflasi, nilai tukar, pendapatan nasional dan kebijakan pemerintah dapat mempengaruhi bisnis ekspor dan impor. Jika tingkat inflasi suatu negara meningkat relatif terhadap negaranegara tempat perdagangannya, maka transaksi berjalannya diperkirakan akan menurun. Oleh karena itu, konsumen dan perusahaan lokal diharapkan untuk membeli barangbarang asing karena harga lokal yang tinggi, yang mengakibatkan penurunan ekspor negara itu. Fluktuasi dan ketidakpastian dalam tingkat Inflasi tidak hanya menciptakan kesulitan dalam ekonomi tetapi juga dalam domain perdagangan eksternal suatu negara.

Seiring dengan inflasi, jika suatu nilai mata uang suatu negara mulai naik nilainya terhadap mata uang lain, maka saldo neraca berjalannya akan berkurang. Di sisi lain, 
ketika mata uang menguat, barang-barang lokal yang akan diekspor menjadi relatif lebih mahal terhadap produk-produk impor, yang mengakibatkan penurunan ekspor neto. (Uz, 2010) melakukan penelitian untuk mengidentifikasi dampak jangka panjang dan jangka pendek dari nilai tukar pada saldo akun saat ini. Hasil studi empiris (Uz, 2010) menunjukkan bahwa nilai tukar memiliki dampak yang kuat pada transaksi berjalan, tetapi tanda-tanda bervariasi dalam jangka panjang dan pendek. Adapun temuan empiris (Henry dan Longmore, 2003) yang menunjukkan nilai tukar riil tidak berkontribusi dalam menentukan elemen-elemen utama dari neraca berjalan Jamaika. Sebuah studi yang dilakukan oleh (Ozdamar, 2015) menemukan bahwa nilai tukar riil mempengaruhi saldo akun Turki secara tidak signifikan. Hasil empiris lainnya oleh (Walter et al., 2012) menunjukkan bahwa baik dalam jangka pendek dan jangka panjang, impor dan ekspor AS sangat sensitif terhadap perubahan dalam pendapatan AS dan asing, sedangkan impor dan ekspor AS relatif tidak sensitif terhadap perubahan nilai tukar bilateral. Selain itu hasil empiris (Walter et al., 2012) ditemukan bahwa baik ekspor maupun impor lebih responsif terhadap perubahan pengeluaran pemerintah daripada perubahan tingkat suku bunga jangka pendek maupun jangka panjang.

Pemerintah dapat memberikan kebijakan tentang mensubsidi eksportir, pembatasan impor dengan menetapkan tarif tinggi atau kurangnya penegakan pembajakan (Madura, 2010). Salah satu penilaian terhadap tata kelola pemerintah atau negara yaitu Worldwide Governance Indicators (WGI) merupakan suatu proyek penelitian jangka panjang untuk mengembangkan indikator tata kelola lintas negara dan merupakan indikator tata kelola komposit agregat berdasarkan enam dimensi dari 215 negara dan wilayah selama periode 1996-2018. Worldwide Governance Indicators (WGI) telah menjadi populer dalam analisis politik komparatif (Langbein and Knack, 2010). WGI memiliki enam indikator gabungan dimensi luas pemerintahan yang mencakup lebih dari 200 negara sejak 1996 yaitu: 1) Suara dan Akuntabilitas, 2) Stabilitas Politik dan Tidak Ada Kekerasan/Terorisme, 3) Efektivitas Pemerintah, 4) Kualitas Pengaturan, 5) Peraturan Hukum, dan 6) Pengendalian Korupsi. Indikator-indikator ini didasarkan pada beberapa ratus variabel yang diperoleh dari 31 sumber data yang berbeda, untuk menangkap persepsi tata kelola seperti yang dilaporkan oleh responden survei, organisasi nonpemerintah, penyedia informasi bisnis komersial, dan organisasi sektor publik di seluruh dunia (Kaufmann et al., 2010).

Trade Openness atau keterbukaan perdagangan merupakan jumlah impor dan ekspor yang dinormalisasi oleh PDB. Trade Openness memungkinkan investor untuk memiliki informasi akuntansi dan peraturan yang lebih baik tentang pasar asing dan dengan demikian berinvestasi dalam aset asing. Hal ini merupakan faktor penting dari keterbukaan terhadap perdagangan internasional meningkatkan skala potensi penjualan di pasar dan meningkatkan tekanan kompetitif. Lebih jauh, perdagangan meningkatkan daya tarik pengetahuan dan menciptakan teknologi baru melalui penyebaran dan penelitian produkproduk impor (De Groot et al., 2004). Negara-negara yang telah mengadopsi dan mempraktikkan kebijakan pasar terbuka di bidang perdagangan, investasi, dan perbankan melakukan lebih baik daripada yang proteksionis atau yang menghindari hubungan ekonomi dengan yang lain (Miller et al., 2019). Di samping itu menurut hasil riset (Semancikova, 2016) bahwa perdagangan, keterbukaan perdagangan dan kinerja makroekonomi memiliki hubungan postif signifikan. 
Data tentang keterbukaan perdagangan berasal dari indikator pembangunan World Bank. Keterbukaan perdagangan yang positif dan signifikan menyiratkan bahwa faktorfaktor yang merangsang perdagangan barang dan jasa juga merangsang perdagangan aset. Perdagangan barang dan jasa dan perdagangan aset adalah kegiatan yang saling melengkapi (Alotaibi and Mishra, 2014). Selain itu (Chakrabarti, 2018) menyatakan bahwa keterbukaan yang lebih tinggi memungkinkan peluang diversifikasi yang lebih besar, tetapi memberikan kekebalan yang lebih rendah dari guncangan luar.

Berdasarkan pemaparan konsep teoritis dan studi empiris dari riset-riset sebelumnya, maka penelitian ini akan menguji faktor makroekonomi yang terdiri dari Tingkat Inflasi, Nilai Tukar Mata Uang Lokal terhadap USD, jumlah Angkatan Kerja, Teknologi, faktor Tata Kelola Negara yang dapat diproksikan dengan indikator Efektivitas Pemerintah dalam Kebijakannya dan variabel Keterbukaan Perdagangan terhadap perdagangan internasional Intra-OKI untuk selanjutnya dapat dianalisis hubungan dan pengaruh signifikansinya sebagai bahan masukan dalam membuat kebijakan perdagangan luar negeri intra-OKI.

\section{METODELOGI}

Pendekatan penelitian ini yaitu kuantitatif dengan menggunakan metode regresi panel data yang merupakan gabungan dari data time series dan cross section. Penerapan teknik regresi bertujuan untuk mengetahui pengaruh antar variabel serta menganalisis tingkat signifikansinya. Data panel menurut (Gujarati dan Porter, 2009) memiliki beberapa keunggulan antara lain dapat mengontrol heterogenitas individu, mampu memberikan analisis lebih informatif, memiliki lebih banyak variabilitas, lebih sedikit kolinearitas antar variabel, lebih banyak derajat kebebasan dan lebih banyak efisiensi serta mampu mempelajari dinamika perubahan. Penggunaan metode kuantitatif melalui metode regresi data panel pada penelitian ini untuk menguji faktor-faktor yang mempengaruhi perdagangan internasional dari 10 Negara pada Intra-OKI sejak tahun 2005 hingga 2018. Fungsi perdagangan internasional (International Trade) dalam penelitian ini ditulis sebagai berikut:

$$
\mathrm{ITit}=\alpha+\beta 1 \text { CPIit }+\beta 2 \text { ERit }+\beta 3 \text { LBFit }+\beta 4 \text { TECHit }+\beta 5 \text { GEit }+\beta 6 \text { TOit }+\varepsilon \text { it }
$$

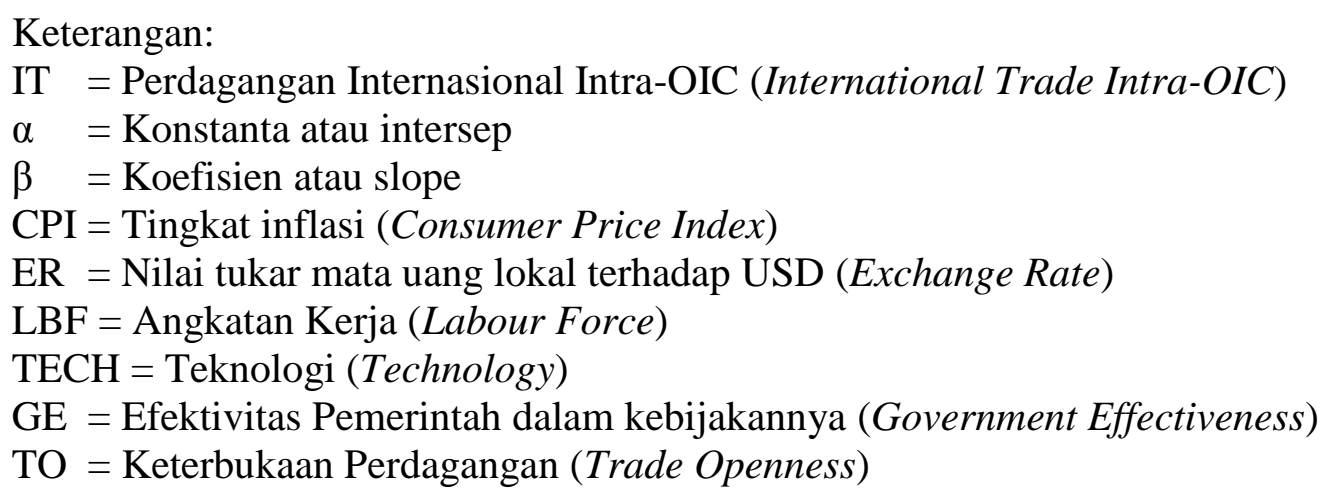

Berdasarkan Fungsi Matematis 3.1 bahwa variabel terikat yang digunakan dalam penelitian ini adalah Perdagangan Internasional Intra-OKI (International Trade Intra-OIC) 
yang diambil dari Statistical, Economic and Social Research and Training Centre for Islamic Countries (SESRIC). Adapun variabel bebas penelitian ini antara lain Consumer Price Index (CPI), Exchange Rate (ER), Labour Force (LBF), Technology (TECH) diambil dari SESRIC, selain itu variabel bebas lainnya adalah Worldwide Governance Indicators (WGI) yang diproksikan dengan indikator Government Effectiveness yang diunduh dari laman elektronik resmi Bank Dunia (World Bank) serta variabel bebas Trade Openness yang diambil dari website The Global Economy.

Jumlah data yang digunakan sebanyak 140 observasi yang diperoleh dari jumlah periode penelitian $(\mathrm{t}=14)$ dan jumlah negara yang digunakan $(\mathrm{n}=10)$, namun karena variabel Technologi tidak memiliki data yang lengkap, yakni data hanya tersedia selama 13 periode dari berbagai negara dalam penelitian, maka jumlah data yang digunakan hanya 127 observasi. Populasi dalam penelitian ini adalah keseluruhan negara yang menjadi anggota OKI. Sementara teknik pengambilan sampel yang digunakan adalah teknik purposive sampling. Hal yang menjadi bahan pertimbangan dalam menentukan sampel yang digunakan di penelitian ini yaitu Negara yang memiliki persentase umat Muslim yang lebih besar dibanding dengan umat agama lain; Negara dengan keterbukaan ekonomi (free market economy); serta Negara yang termasuk pemain utama dalam perdagangan internasional Intra-OKI pada tahun 2017 berdasarkan publikasi terakhir oleh OKI. Berdasarkan kriteria pengambilan sampel tersebut, maka terpilihlah 10 negara muslim yang tergabung dalam OKI yaitu Uni Arab Emirat (UAE), Turkey, Saudi Arabia, Malaysia, Indonesia, Egypt, Oman, Pakistan, Qatar dan Kuwait.

Penelitian ini penulis menggunakan regresi data panel dengan menggunakan software EViews 10 untuk pengolahan data. (Gujarati dan Porter, 2009) menyatakan bahwa beberapa metode yang dapat digunakan untuk mengestimasi model regresi dengan menggunakan data panel, antara lain pooling least square (common effect), pendekatan efek tetap (fixed effect), pendekatan efek random (random effect). Pengujian untuk dapat memilih model yang terbaik antara model common effect dengan model fixed effect dengan pendekatan model Least Square Dummy Variabel (LSDV) adalah dengan uji redundant-fixed effect. Adapun pengujian untuk memilih model yang terbaik antara model fixed effect dengan model random effect dapat dilakukan dengan uji hausman, sedangkan pengujian untuk memilih model yang terbaik antara model common effect dengan model random effect dapat dilakukan dengan uji LM (lagrange multiplier). Selanjutnya akan dilakukan uji kriteria statistik antara lain uji F, Uji Signifikansi Parameter Individual (Uji Statistik T) dan Koefisien Determinasi $\left(\mathrm{R}^{2}\right)$.

\section{HASIL DAN PEMBAHASAN}

Sebelum melakukan perhitungan regresi dari sampel data panel terpilih, penulis melakukan analisis statistik deskriptif. Analisis statistik deskriptif digunakan untuk melihat gambaran umum dari 127 observasi atas variabel dependen dan independen yang digunakan pada model regresi data panel yaitu sebagai berikut: 
Tabel 1. Hasil Analisis Statistik Deskriptif Variabel Dependen dan Independen

\begin{tabular}{lccccccc}
\hline & $\ln$ IT & CPI & $\ln$ ER & In LBF & In TECH & GE & TO \\
\hline Mean & 10.24688 & 5.926220 & 2.077434 & 16.24991 & 19.20953 & 0.205109 & 76.19370 \\
Median & 10.23124 & 4.530000 & 1.300192 & 16.36482 & 19.13815 & 0.197932 & 77.20000 \\
Maximum & 11.56446 & 23.54000 & 9.563595 & 18.69174 & 24.90109 & 0.265107 & 86.80000 \\
Minimum & 8.299142 & -4.880000 & -1.309333 & 13.20711 & 9.112286 & 0.169267 & 54.60000 \\
Std. Dev. & 0.737658 & 4.590020 & 2.967767 & 1.524746 & 3.341538 & 0.020335 & 7.223053 \\
Observations & 127 & 127 & 127 & 127 & 127 & 127 & 127 \\
\hline \multicolumn{5}{l}{ Sumber: (Hasil Penelitian, 2019) }
\end{tabular}

Tabel 1. menunjukkan hasil analisis statistik deskriptif International Trade (IT) Intra-OKI sebagai variabel dependen menunjukkan nilai tertinggi sebesar USD 106842,21 yang dimiliki oleh Uni Emirat Arab (UAE) pada tahun 2018, sedangkan nilai terendah USD 4020,42 dimiliki oleh Qatar pada tahun 2005. Nilai Inflasi tertinggi dimiliki oleh Egypt tahun 2017 sebesar 23,54 persen, sedangkan nilai inflasi terendah yaitu $-4,88$ persen pada tahun 2009 yang dimiliki oleh Qatar, adapun rata-rata inflasi pada 10 negara IntraOKI sebesar 4,53 persen sejak tahun 2005 hingga 2018. Jumlah Angkatan Kerja (Labour Force) yang memiliki nilai tertinggi yaitu di Indonesia sebesar 131.135.747, sedangkan nilai terendah jumlah Angkatan Kerja dimiliki oleh Qatar pada tahun 2005 sebesar 544.223 ribu orang, adapun rata-rata jumlah Angkatan Kerja pada 10 negara Intra-OKI selama periode penelitian sebesar 26.893.885,46 juta orang. Nilai Technology (HighTechnology Exports/USD) terbesar yaitu 65.223.947.548 USD di Malaysia pada tahun 2007, sedangkan nilai terendah 9066 USD di Qatar pada tahun 2008.

Di sisi lain untuk variabel Worldwide Governance Indicators atau tata kelola pemerintah, nilai tertinggi dari indikator Government Effectiveness yaitu di Oman pada tahun 2006 sebesar 0,2651074 sedangkan yang terendah sebesar 0,1692666 di Indonesia pada tahun 2005 dan rata-rata nilainya sebesar 0.205109 di 10 negara Intra-OKI. Nilai Government Effectiveness (GE) atau Efektivitas Pemerintah dalam kebijakannya artinya memperoleh persepsi terkait kualitas layanan publik, kualitas layanan sipil dan tingkat kemandiriannya dari tekanan politik, kualitas formulasi dan implementasi kebijakan, dan kredibilitas serta komitmen pemerintah terhadap kebijakan tersebut.

Variabel Trade Openness atau keterbukaan pedagangan memiliki nilai rata-rata sebesar 76.19370 di 10 negara Intra-OKI selama jangka waktu penelitian yaitu 2005-2018, nilai tertinggi dari Trade Openness sebesar 86.8 di Turki pada tahun 2008 sampai 2009, sedangkan nilai terendah 54.6 di Pakistan pada tahun 2005, adapun rata-ratanya sebesar 76.19 yang termasuk kategori "Mostly Free", nilai ini artinya bahwa 10 negara Intra-OKI sebagian besar memiliki keterbukaan perdagangan yang baik. 
Tabel 2. Hasil Uji Hausman

\begin{tabular}{cccc}
\hline Test Summary & Chi-Sq. Statistic & Chi-Sq. d.f. & Prob. \\
\hline Cross-section random & 45.570168 & 4 & 0.0000
\end{tabular}

Sumber: (Hasil Penelitian, 2019)

Berdasarkan Tabel 2. bahwa dalam penilaian Uji Hausman, $\mathrm{H}_{0}$ yang menyatakan model Random Effect lebih baik dari pada model Fixed Effect akan diterima jika nilai probabilitas cross-section random lebih besar dari pada confidence level lima persen $(\alpha=$ $0,05)$. Namun sebaliknya, Ha diterima ( $\mathrm{H}_{0}$ ditolak) jika nilai probabilitas cross-section random lebih kecil dari pada confidence level lima persen $(\alpha=0,05)$, sehingga model fixed effect akan dipilih dan lebih baik dari pada model common effect. Hasil pengujian Hausman menunjukkan nilai probabilitas cross-section random sebesar 0,0000 dan signifikan terhadap confidence level lima persen (lebih kecil dari $\alpha=0,05$ ), sehingga diputuskan bahwa model fixed effect dengan pendekatan within group estimator lebih baik daripada common effect (fixed effect dengan pendekatan within group estimator terpilih). Hasil regresi berdasarkan model yang disarankan yaitu model Fixed Effect dengan pendekatan within group estimator akan dijabarkan pada Tabel 3.

Tabel 3. Hasil Regresi (1)

\begin{tabular}{|c|c|c|c|c|c|c|c|c|}
\hline \multirow[t]{2}{*}{ Variable } & \multicolumn{2}{|c|}{$\begin{array}{c}\text { Model 1 } \\
\begin{array}{c}\text { Pooled Least Square } \\
\text { Common Effect }\end{array} \\
\end{array}$} & \multicolumn{2}{|c|}{$\begin{array}{c}\text { Model } 2 \\
\text { Random Effect }\end{array}$} & \multicolumn{2}{|c|}{$\begin{array}{c}\text { Model 3 } \\
\text { Fixed Effect } \\
\text { Within-Group Estimator } \\
\end{array}$} & \multicolumn{2}{|c|}{$\begin{array}{c}\text { Model 4 } \\
\text { Government Effectiveness } \\
\text { Fixed Effect }\end{array}$} \\
\hline & Coefficient & t-statistics & Coefficient & t-statistics & Coefficient & t-statistics & Coefficient & t-statistics \\
\hline CPI & -0.013930 & -1.343496 & 0.008628 & 1.295611 & $0.017610^{* *}$ & 2.510881 & $0.013419^{*}$ & 1.906770 \\
\hline $\ln \mathrm{ER}$ & $-0.100887 * * *$ & -4.139560 & $-0.258224 * * *$ & -3.673085 & 0.002830 & 0.024225 & 0.009936 & 0.087125 \\
\hline $\ln \mathrm{LBF}$ & $0.602083 * * *$ & 7.590113 & $1.048983^{* * *} *$ & 9.391550 & $1.406781 * * *$ & 10.90592 & $1.288206^{* * *}$ & 9.606219 \\
\hline $\ln \mathrm{TECH}$ & 0.023041 & 1.242278 & $0.050195^{* *}$ & 2.422421 & 0.032214 & 1.495089 & $0.043807 * *$ & 2.036558 \\
\hline GE & & & & & & & $5.429441 * *$ & 2.569268 \\
\hline \multicolumn{9}{|l|}{ PV } \\
\hline \multicolumn{9}{|l|}{ VA } \\
\hline \multicolumn{9}{|l|}{ TO } \\
\hline Constant & $-7.730575^{* * *}$ & -3.706815 & $-7.206422 * * *$ & -4.487614 & $-13.34224 * * *$ & -7.078502 & $-12.74166^{* * * *}$ & -6.870154 \\
\hline F-statistics & $29.64837 * * *$ & & $31.88969 * * *$ & & $85.85054 * * *$ & & $84.14132 * * *$ & \\
\hline $\mathrm{R} 2$ & 0.667781 & & 0.511137 & & 0.908060 & & 0.913177 & \\
\hline Adjusted R2 & 0.645257 & & 0.495109 & & 0.897482 & & 0.902324 & \\
\hline Durbin Watson & 0.475715 & & 0.583735 & & 0.806968 & & 0.844188 & \\
\hline Adjusted Obs. & 127 & & 127 & & 127 & & 127 & \\
\hline
\end{tabular}

Sumber: (Hasil Penelitian, 2019)

Keterangan

* Signifikan pada tingkat confidence level sepuluh persen (lebih kecil dari $\alpha=0,10$ )

** Signifikan pada tingkat confidence level lima persen (lebih kecil dari $\alpha=0,05$ )

$* * *$ Signifikan pada tingkat confidence level satu persen (lebih kecil dari $\alpha=0,01$ ) 
Berdasarkan Tabel 3. peneliti mencantumkan model dengan efek common, efek random dan efek fixed sebagai bahan perbandingan. Hasil Uji T ini merupakan pengujian bagi masing-masing variabel independen pada model penelitian. Dalam uji $\mathrm{T}$, fokus penelitian terdapat dua hal yaitu uji arah atas nilai koefisien dari masing-masing variabel dan uji signifikansi dengan melihat probabilitas $p$-value atau membandingkan antara nilai t-hitung dengan nilai t-tabel. Secara umum hasil Uji T pada setiap model dengan efek common menunjukkan bahwa hanya variabel Nilai Tukar Mata Uang Lokal terhadap USD (ER) yang memiliki hubungan negatif dan Angkatan Kerja (LBF) memiliki hubungan positif signifikan terhadap perdagangan internasional Intra-OKI, sedangkan tingkat inflasi dan teknologi tidak memiliki pengaruh signifikan. Di sisi lain hasil pada model efek random hanya variabel tingkat inflasi saja yang tidak berpengaruh signifikan terhadap perdagangan internasional Intra-OKI. Hasil estimasi selanjutnya pada model 3 dan 4 yang menggunakan model efek fixed bahwa tingkat inflasi dan Angkatan Kerja secara konsisten memiliki pengaruh positif signifikan dan pada model 4 terdapat variabel Government Effectiveness yang memiliki pengaruh positif signifikan terhadap perdagangan internasional Intra-OKI.

Hasil uji $\mathrm{F}$ dilakukan untuk mengetahui pengaruh variabel-variabel independen terhadap variabel dependen secara simultan. Tabel 3. menunjukkan bahwa dari model fixed effect dalam model 3 dengan pendekatan within group estimator diperoleh nilai hitung F sebesar 85.85054 dengan probabilitas 0,0000 . Adapun pada model 4 bahwa nilai hitung F sebesar 84.14132 dengan probabilitas 0,0000 . Nilai $P$ value kurang dari 0,05 , artinya bahwa secara simultan model fixed effect dalam model 3 dan 4 berpengaruh signifikan terhadap Log Natural atas Perdagangan Internasional (IT) di 10 negara Muslim Intra-OKI pada periode 2005 sampai 2018. Di sisi lain, secara keseluruhan model 3 pada Tabel 3. menunjukkan hasil uji regresi panel dengan menggunakan fixed effect model diperoleh angka $\mathrm{R}^{2}$ sebesar 0.908060 atau 90,8 persen, sedangkan sisanya sebesar 9,2 persen dipengaruhi atau dijelaskan dari variabel lain di luar model estimasi. Adapun nilai $\mathrm{R}^{2}$ pada model 4 sebesar 0.913177 atau 91,31 persen, sedangkan sisanya sebesar 8,69 persen dipengaruhi atau dijelaskan dari variabel lain di luar model estimasi.

Tabel 4. Hasil Regresi (2)

\begin{tabular}{lll}
\hline & Variable & \multicolumn{2}{c}{$\begin{array}{c}\text { Model 5 } \\
\text { Trade Openess Fixed Effect }\end{array}$} \\
\cline { 2 - 3 } & \multicolumn{1}{c}{ Coefficient } & t-statistics \\
\hline CPI & $0.016710^{* *}$ & 2.540435 \\
$\ln$ ER & -0.041072 & -0.373343 \\
$\ln$ LBF & $1.262835^{* * *}$ & 10.02572 \\
$\ln$ TECH & 0.015491 & 0.751659 \\
GE & & \\
TO & $0.021212^{* * *}$ & 4.076259 \\
Constant & $-12.20158^{* * * *}$ & -6.821136 \\
F-statistics & $91.92179^{* * *}$ & \\
R2 & 0.919937 &
\end{tabular}




$\begin{array}{ll}\text { Adjusted R2 } & 0.909930 \\ \text { Durbin Watson } & 1.021565 \\ \text { Adjusted Obs. } & 127\end{array}$

Sumber: (Hasil Penelitian, 2019)

Keterangan

* Signifikan pada tingkat confidence level sepuluh persen (lebih kecil dari $\alpha=0,10$ )

** Signifikan pada tingkat confidence level lima persen (lebih kecil dari $\alpha=0,05$ )

*** Signifikan pada tingkat confidence level satu persen (lebih kecil dari $\alpha=0,01$ )

Berdasarkan hasil Uji T secara keseluruhan dari masing-masing model pada Tabel 4. bahwa variabel tingkat inflasi (CPI) dan total Angkatan Kerja (LBF) memiliki hubungan positif signifikan terhadap perdagangan internasional Intra-OKI. Di sisi lain adanya variabel keterbukaan perdagangan (Trade Openness) memiliki hubungan positif signifikan terhadap perdagangan internasional Intra-OKI. Selain itu secara keseluruhan semua variabel dalam model 6 menunjukkan bahwa variabel tingkat inflasi (CPI), Angkatan Kerja (LBF), Government Effectiveness (GE) dan Trade Openness (TO) memiliki hubungan positif signifikan, sedangkan Nilai Tukar Mata Uang Lokal terhadap USD (ER) dan Teknologi (TECH) tidak memiliki pengaruh signifikan terhadap perdagangan internasional Intra-OKI.

Tabel 5. Hasil Regresi (3)

\begin{tabular}{lll}
\hline & \multicolumn{1}{c}{ Variable } & \multicolumn{1}{c}{$\begin{array}{c}\text { Model 6 } \\
\text { All variables Fixed Effect }\end{array}$} \\
\cline { 2 - 3 } CPI & \multicolumn{1}{c}{ Coefficient } & t-statistics \\
In ER & $0.011844^{*}$ & 1.819724 \\
In LBF & -0.035899 & -0.339266 \\
In TECH & $1.117139^{* * *}$ & 8.624447 \\
GE & 0.027648 & 1.369665 \\
TO & $6.224719^{* * *}$ & 3.176546 \\
Constant & $0.022649 * * *$ & 4.507260 \\
F-statistics & $-11.43574^{* * *}$ & -6.583054 \\
R2 & $93.42978^{* * *}$ & \\
Adjusted R2 & 0.926609 & \\
Durbin Watson & 0.916691 & \\
Adjusted Obs. & 1.036415 & \\
\hline Sumber: (Hasil Penelitian & 127 & \\
\hline
\end{tabular}

Sumber: (Hasil Penelitian, 2019)

Di samping itu, hasil Uji $\mathrm{F}$ untuk mengetahui pengaruh variabel-variabel bebas terhadap variabel terikat secara simultan. Tabel 5. menunjukkan bahwa dari model fixed 
effect yang memasukkan semua variabel dalam model penelitian dengan pendekatan within group estimator diperoleh nilai hitung $\mathrm{F}$ sebesar 93.42978 dengan probabilitas 0,0000 . Nilai $P$ value kurang dari 0,05 , artinya bahwa secara simultan berpengaruh signifikan terhadap Log Natural atas Perdagangan Internasional (IT) di 10 negara Muslim Intra-OKI pada periode 2005 sampai 2018. Di sisi lain, secara keseluruhan pada model 6 yang menggunakan semua variabel menunjukkan hasil uji regresi panel dengan menggunakan fixed effect model diperoleh angka $\mathrm{R}^{2}$ sebesar 0.926609 atau 92,66 persen, sedangkan sisanya sebesar 7,34 persen dipengaruhi atau dijelaskan dari variabel lain di luar model estimasi.

Secara umum hubungan antara pengaruh Tingkat Inflasi, Log Natural atas Nilai Tukar Mata Uang terhadap USD, Log Natural atas Jumlah Angkatan Kerja, Log Natural atas Teknologi, Tata Kelola Pemerintah dari Efektivitas Pemerintah dalam kebijakannya dan variabel Keterbukaan Perdagangan terhadap Log Natural atas Perdagangan Internasional (IT) di 10 negara Muslim Intra-OKI pada periode 2005 sampai 2018 dapat diukur melalui persamaan sebagai berikut:

$\ln \left(\mathrm{IT}_{\mathrm{it}}\right)=-11.43574+0.011844(\mathrm{CPI})_{\mathrm{it}}-0.035899 \ln (\mathrm{ER})_{\mathrm{it}}+1.117139 \ln (\mathrm{LBF})_{\mathrm{it}}+0.027648$ $\ln (\mathrm{TECH})_{\mathrm{it}}+6.224719(\mathrm{GE})_{\mathrm{it}}+0.022649(\mathrm{TO})+\varepsilon \mathrm{i}$

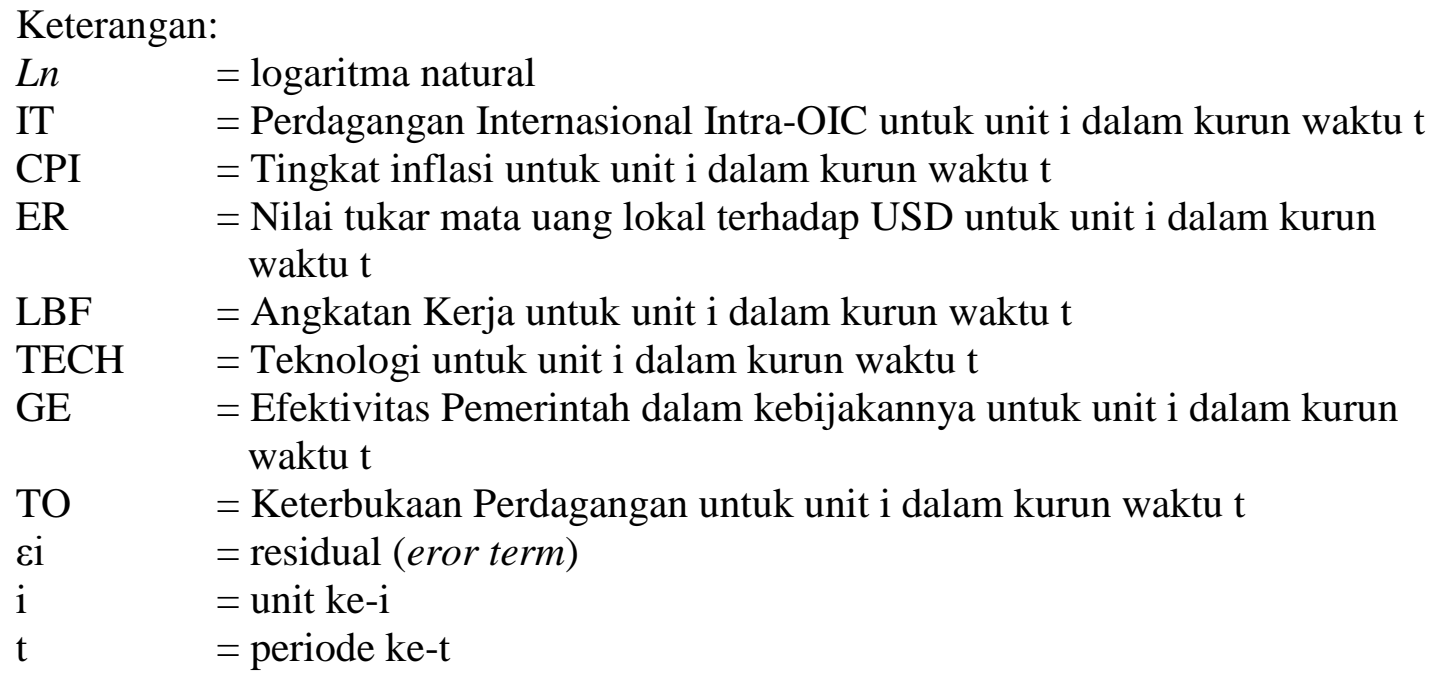

Perkembangan perdagangan internasional Intra-OKI setelah stabil sekitar US \$ 390 miliar selama 2012-2014, ekspor intra-OKI menurun menjadi US \$ 274 miliar pada 2016. Sejalan dengan ekspansi perdagangan global, total ekspor intra-OIC mencapai US \$ 319 miliar pada 2017. Meskipun terjadi fluktuasi pada perdagangan intra-OKI, pangsa perdagangan intra-OKI dalam total perdagangan negara-negara OKI terus meningkat selama periode 2011-2017 dan mencapai 19,9\% pada 2017 dibandingkan dengan levelnya $17,5 \%$ pada 2011 . UEA menempati peringkat pertama dengan US \$ 71,4 miliar dan $22,4 \%$ dari total ekspor intra-OIC (Sesric, 2018).

Hasil pengujian empiris pada variabel makro tingkat inflasi (CPI) menunjukkan pengaruh yang signifikan terhadap perdagangan internasional Intra-OKI. Pengujian empiris ini ditujukkan oleh perkembangan tingkat Inflasi yang meningkat di seluruh dunia terutama mencerminkan dampak kenaikan harga minyak dan komoditas lainnya. Di 
negara-negara OKI, tingkat inflasi rata-rata untuk 2017 lebih tinggi dari rata-rata dunia. Berbeda dengan tren global, inflasi di negara-negara OKI tetap stabil di sekitar 6,5\%. Indeks Harga Konsumen rata-rata menandai peningkatan 26,5\% di negara-negara OKI selama 2012-2017. Namun, hal ini jauh di bawah peningkatan rata-rata yang tercatat di negara-negara berkembang non-OKI sebesar 30,4\% dan hampir dua kali lipat peningkatan global sebesar 13,8\% selama periode yang sama (Sesric, 2018).

Hasil temuan penelitian ini berkaitan dengan pernyataan bahwa kualitas birokrasi dan kerangka kerja kelembagaan menurut (Busse dan Hefeker, 2007) akan mendorong aliran investasi asing. Oleh karena itu, kerangka kerja yang layak dari pemerintah dan institusi perusahaan memiliki pengaruh dalam pembentukan strategi internasionalisasi dan diversifikasi perusahaan asing. Adapun temuan riset (Asamoah et al., 2016) menyebutkan bahwa kualitas kelembagaan baik dalam lingkup pemerintah maupun kelembagaan pada level perusahaan dan industri akan meningkatkan portofolio investasi di negara tertentu. Menurut (Muslim, 2016) bahwa investor cenderung melakukan bisnis dan menanamkan modal portofolio mereka di negara-negara yang memiliki prospek pertumbuhan ekonomi yang baik. Di samping itu, kinerja dan kualitas kelembagaan yang mengarah pada kemudahan untuk melakukan bisnis menurut (Aziz, 2018) akan meningkatkan investasi. Temuan ini sejalan dengan hasil riset (Asamoah et al., 2016) dan (Mina, 2007). Di sisi lain menurut (Herrera et al., 2014) bahwa hubungan antara tata kelola negara untuk menarik investasi asing memiliki hubungan positif signifikan.

Di sisi lain menurut temuan empiris (Binici, 2012) terdapat bukti bahwa keterbukaan keuangan dan globalisasi akan merangsang pertumbuhan ekonomi. Singkatnya, karena sebagian besar bank sentral menggunakan fungsi kerugian (loss function) yang mempertimbangkan penyimpangan inflasi dan output dari target mereka, hal ini adalah mungkin untuk menduga bahwa liberalisasi keuangan dan globalisasi ekonomi dapat membawa manfaat bagi pengelolaan kebijakan moneter serta stabilitas makroekonomi. Sedangkan menurut (De Mendonca dan Veiga, 2014) bahwa adanya peningkatan keterbukaan keuangan dan globalisasi dapat meningkatkan komitmen bank sentral terhadap target inflasi berkontribusi pada konvergensi antara ekspektasi inflasi dan target.

Selain itu menurut (Mendonca dan Nascimento, 2018) menyebutkan bahwa meskipun keterbukaan finansial dan globalisasi dapat berguna bagi manajemen kebijakan ekonomi, kita tidak dapat mengabaikan kemungkinan efek yang merugikan. Misalnya, dalam kasus ekonomi berkembang, peningkatan keterbukaan dan globalisasi membuat ekonomi ini lebih rentan terhadap guncangan eksternal, yang pada gilirannya dapat merusak manajemen kebijakan ekonomi untuk pertumbuhan ekonomi dengan stabilitas harga. Temuan empiris penelitian ini menemukan bahwa Angkatan Kerja (LBF) memiliki hubungan positif signifikan terhadap perdagangan internasional Intra-OKI. Hal ini sebagaimana hasil riset (Cacciatore, 2014) terkait hubungan perdagangan yang lebih kuat mengarah pada peningkatan sinkronisasi siklus bisnis. Namun, kekuatan efek ini tergantung pada karakteristik pasar tenaga kerja dari mitra yang terintegrasi.

Variabel teknologi dalam penelitian ini tidak memiliki pengaruh signifikan terhadap perdagangan internasional Intra-OKI. Hal ini berdasarkan fakta bahwa rata-rata wilayah OKI belum memiliki inovatif yang tinggi, dan persaingannya dalam ekonomi global sebagian besar didasarkan pada biaya tenaga kerja, bukan nilai tambah (value added). Oleh karena itu untuk mengatasi kesenjangan infrastruktur teknologi serta kendala kapasitas, maka pengalaman negara-negara berkembang yang sukses menunjukkan bahwa 
kebijakan IMS harus diintegrasikan ke dalam strategi pembangunan nasional, didukung oleh investasi nasional dan internasional yang memadai, berkomitmen untuk kerja sama yang melibatkan badan publik dan swasta, serta didukung oleh mekanisme yang memastikan implementasi yang efektif. Adapun temuan hasil empiris (Alam dan Murad, 2019) mengungkapkan bahwa pertumbuhan ekonomi, keterbukaan perdagangan dan kemajuan teknologi secara signifikan mempengaruhi penggunaan energi terbarukan dalam jangka panjang di negara-negara Organization for Economic Co-operation and Development (OECD).

Selain itu peran Sains, Teknologi, dan Inovasi (STI) merupakan salah satu pendorong terpenting pembangunan ekonomi dan sosial. Perubahan produktivitas dan daya saing terkait erat dengan kemajuan teknologi dan inovasi. Tanpa investasi pada sektor ini, maka hasil dari upaya yang ditujukan untuk mengatasi tantangan masyarakat yang mendesak dan membangun kapasitas produktif di negara-negara berkembang akan tetap terbatas. Program Aksi OIC-2025, OKI bertujuan untuk memajukan pengembangan ilmu pengetahuan, teknologi dan inovasi untuk pembangunan berkelanjutan melalui peningkatan penelitian, kemampuan teknologi di semua sektor, inovasi dan pengembangan teknologi dalam negeri dengan memastikan lingkungan kebijakan yang kondusif dan selaras dengan keputusan negara OKI yang terkait. Dengan demikian adanya integrasi perdagangan akan bermanfaat untuk kesejahteraan dengan mendorong produktivitas yang lebih tinggi (Cacciatore, 2014).

Berdasarkan hasil pengujian empiris pada penelitian ini menemukan bahwa perdagangan internasional mampu memperkuat ikatan antar negara intra-OKI dan memiliki potensi untuk menghasilkan manfaat ekonomi yang signifikan di antara negaranegara OKI. Kegiatan perdagangan intra-OKI cenderung mendorong perkembangan UKM dan sektor swasta di negara-negara OKI dengan meningkatkan daya saing mereka. Akibatnya, UKM dan sektor swasta secara efektif melakukan spesialisasi pada produk dan layanan di mana mereka memiliki keunggulan komparatif. Kegiatan perdagangan IntraOKI juga membantu mengurangi pengangguran dengan menciptakan peluang kerja baru karena ukuran pasar yang meningkat dan mengurangi ketidakefisienan. Meningkatkan ikatan perdagangan antara negara-negara OKI berkontribusi pada pengembangan kerja sama komersial di wilayah OKI serta mendukung pembangunan berkelanjutan (Sesric, 2018).

Berdasarkan hasil pengujian empiris menunjukan bahwa variabel Angkatan Kerja (Labour Force) memiliki konsistensi nilai pengaruh positif signifikan terhadap perdagangan internasional Intra-OKI. Hal ini berdasarkan faktanya bahwa Negara-negara OKI saat ini menghadapi tantangan pasar tenaga kerja utama dalam meningkatkan kemampuan kerja, menciptakan lapangan kerja dan melindungi tenaga kerja. Pemerintah harus berinvestasi dan menciptakan kondisi untuk meningkatkan pendidikan dan pelatihan di semua tingkatan untuk meningkatkan produktivitas. Namun, banyak negara OKI membutuhkan dukungan dalam perancangan dan implementasi kebijakan pendidikan dan pelatihan yang tepat untuk mencapai pembangunan manusia, produktivitas, dan pertumbuhan ekonomi. Di sisi lain faktor dari efektivitas pemerintah dan keterbukaan perdagangan perlu menjadi perhatian karena terbukti memiliki pengaruh positif signifikan terhadap volume perdagangan internasional negara Intra-OKI. 


\section{KESIMPULAN}

Perdagangan internasional merupakan kontribusi penting bagi perekonomian negara. Faktor makroekonomi yang memiliki pengaruh signifikan terhadap perdagangan internasional yaitu variabel inflasi dengan pengaruh positif signifikan, sedangkan nilai tukar mata uang lokal terhadap USD tidak memiliki pengaruh signifikan dalam menentukan perdagangan Intra-OKI. Jumlah Angkatan Kerja merupakan satu-satunya variabel yang memiliki konsistensi pengaruh positif signifikan dalam setiap model, sedangkan faktor teknologi tidak memiliki peranan terhadap perdagangan Intra-OKI. Hasil dari tata kelola negara yang diproksikan dari efektivitas pemerintah dalam kebijakannya dan keterbukaan perdagangan memiliki pengaruh positif signifikan dalam menentukan kebijakan perdagangan luar negeri Intra-OKI.

Berdasarkan hasil temuan empiris, maka saran bagi pelaku ekonomi adalah menempatkan semua faktor ekonomi makro sebagai pertimbangan penting dalam proses pengambilan keputusan perdagangan internasional. Pelaku ekonomi Intra-OKI perlu menyadari kondisi makroekonomi, tata kelola negara dan keterbukaan perdagangan suatu negara saat merumuskan kebijakan perdagangan internasional agar memperoleh dampak positif bagi pertumbuhan ekonomi dan kesejahteraan masyakatnya. Negara-negara OKI harus merancang kebijakan yang tepat untuk mendorong perdagangan internasional antara anggota yang berpartisipasi maupun dengan negara yang tidak bergabung dalam OKI. Penelitian lebih lanjut diperlukan untuk menemukan dan menganalisa kebijakan pemerintah seperti apa yang akan berdampak signifikan terhadap perdagangan internasional. Di sisi lain dalam masalah perdagangan internasional, fenomena makroekonomi lainnya dalam kebijakan moneter dan fiskal adalah hal fundamental lainnya bagi penelitian selanjutnya untuk menemukan dampaknya terhadap perdagangan internasional, terutama untuk negara-negara Islam. Temuan hasil empiris riset ini diharapkan mampu memberikan masukan serta manfaat yang lebih besar melalui analisa model penelitian yang lebih komprehensif dalam menjelaskan faktor penentu kegiatan perdagangan internasional Intra-OKI.

\section{DAFTAR PUSTAKA}

Al-Qur'an

Alam, M. M. and Murad, M. W. (2019). The Impacts Of Economic Growth, Trade Openness And Technological Progress On Renewable Energy Use In Organization For Economic Cooperation And Development Countries. Renewable Energy, Elsevier Inc, 382-390, https://doi.org/10.1016/j.renene.2019.06.054.

Alotaibi, A. R. and Mishra, A. V. (2014). Determinants of International Financial Integration of GCC Markets. Emerging Markets and the Global Economy, Elsevier Inc, http://dx.doi.org/10.1016/B978-0-12-411549-1.00031-4.

Asamoah, M. E., Adjasi, C. K. D., and Alhassan, A. L. (2016). Macroeconomic Uncertainty, Foreign Direct Investment And Institutional Quality: Evidence from Sub-Saharan Africa. Economic Systems, 40(4), 612-621. https://doi.org/10.1016/j.ecosys.2016.02.010. 
Auboin, M. and Ruta, M. (2013). The Relationship Between Exchange Rates and International Trade: a Literature Review. World Trade Review, pp 577-605 http://journals.cambridge.org/WTR.

Aziz, O. G. (2018). Institutional quality and FDI inflows in Arab economies. Finance Research Letters, 25(August 2016), 111-123. https://doi.org/10.1016/j.frl.2017.10.026.

Baltas, N. C. (2013). The Greek Financial Crisis and the Outlook of the Greek Economy. Journal of Economic Asymmetries, 10(1), 32-37. https://doi.org/10.1016/j.jeca.2013.09.002.

Binici, M., Cheung, Y.-W., and Lai, K. S. (2012). Trade Openness, Market Competition, And Inflation: Some sectoral evidence from OECD countries. International Journal of Finance Economics, 17(4), 321-336.

Busse, M., and Hefeker, C. (2007). Political Risk, Institutions And Foreign Direct Investment. European Journal of Political Economy, 23(2), 397-415. https://doi.org/10.1016/j.ejpoleco.2006.02.003.

Cacciatore, M. (2014). International Trade and Macroeconomic Dynamics with Labor Market Frictions. Journal of International Economics, http://dx.doi.org/10.1016/j.jinteco.2014.01.008.

Chakrabarti, A. S. (2018). Dispersion In Macroeconomic Volatility Between The Core And Periphery Of The International Trade Network. Journal of Economic Dynamics \& Control, https://doi.org/10.1016/j.jedc.2018.01.019.

Committee for Economic and Commercial Cooperation of The Organization of Islamic Cooperation (COMCEC). (2018). COMCEC Trade Outlook. Ankara: COMCEC Coordination Office.

Committee for Economic and Commercial Cooperation of The Organization of Islamic Cooperation (COMCEC). (2019). Annual Report On Trade Among The OIC Member States. Ankara: The Islamic Centre for Development of Trade.

De Groot, H. L. F., Linders, G. J., Rietveld, P., and Subramanian, U. (2004). The Institutional Determinants Of Bilateral Trade Patterns. Kyklos, 57(1), 103-124.

De Mendonca, H. F., and Veiga, I. S. (2014). A note on Openness and Inflation Targeting: Implications for the Unpleasant Fiscal Arithmetic. Macroeconomic Dynamics, 18(5), 1187-1207.

Dumairy. (1999). Perekonomian Indonesia. Jakarta: Penerbit Erlangga.

Gujarati, D. N., and Porter, D. C. (2009). Basic Econometrics (5th ed.). New York: McGraw-Hill/Irwin.

Henry, C., and Longmore, R. (2003). Current Account Dynamics and The Real Effective Exchange Rate: The Jamaican Experience, (March), 1-30.

Herrera-Echeverri, H., Haar, J., and Estévez-Bretón, J. B. (2013). Foreign Direct Investment, Institutional Quality, Economic Freedom And Entrepreneurship In Emerging Markets. Journal of Business Research, 1921-1932. https://doi.org/10.1016/j.jbusres.2013.11.020.

Kang, J. W. and Dagli, S. (2018). International Trade and Exchange Rates. Journal of Applied Economics, Vol. 21, No. 1, 84-105, https://doi.org/10.1080/15140326.2018.1526878.

Kaufmann, D., Kraay, A., and Mastruzzi, M. (2010). The Worldwide Governance Indicators Methodology and Analytical Issues (No. 5430). 
Kayalvizhi, P. N., and Thenmozhi, M. (2018). Does Quality of Innovation, Culture and Governance Drive FDI?: Evidence from Emerging Markets. Journal Emerging Markets Review, 34, 175-191. https://doi.org/10.1016/j.ememar.2017.11.007.

Langbein, L. and Knack, S. (2010). The Worldwide Governance Indicators: Six, One, or None?. Journal of Development Studies, Vol. 46, No. 2, 350-370.

Madanizadeh, S. A. and Pilvar, H. (2019). The Impact Of Trade Openness On Labour Force Participation Rate. Applied Economics, https://doi.org/10.1080/00036846.2018.1558350.

Madura, J. (2010). International Corporate Finance. Joe Sabatino.

Majoka, M. I., Sahibzada, H. E., and Khan, M. S. (2012). Resources of The Muslim World: A Reflection on the Muslim World's Resources, Their Development and Utilization. Journal of Islamic Thought and Civilization (JITC), 2(1).

Mendonca, H. F. D. and Nascimento, N. C. (2018). Monetary Policy Efciency And Macroeconomic Stability: Do Fnancial Openness And Economic Globalization Matter?. North American Journal of Economics and Finance, 1-20. https://doi.org/10.1016/j.najef.2018.10.018.

Miller, T., Kim, A. B., Roberts, J. M. and Tyrrell, P. (2019). Highlight of The 2019 Index of Economic Freedom. Washington, DC: The Heritage Foundation.

Mina, W. (2007). The Location Determinants of FDI in the GCC Countries. Journal of Multinational Financial Management, 17, 336-348. https://doi.org/10.1016/j.mulfin.2007.02.002.

Muslim, A. (2016). Apakah Perdagangan Menjadi Pertimbangan Investasi? Kajian Ekonomi \& Keuangan, 20(2).

Nath, H. K., and Mamun, K. A. A. (2004). Trade Liberalization, Growth And Inequality In Bangladesh: An Empirical Analysis. In: The 41st Annual Conference of the Missouri,Valley Economic Association Held in Nashville. TN.

Octavia, E. R. and Wulandari, D. (2016). Analysis of Effect Macro Variable on International Trade of Indonesia. Business and Economic Research ISSN 21624860, Vol. 6, No. 2.

Ozdamar, G. (2015). Factors Affecting Current Account Balance of Turkey : a Survey With the Cointegrating Regression Analysis. Journal of Business, Economics \& Finance, 4, 633-658.

Pan, X., Uddin, M. K., Saima, U., Jiao, Z. and Han, C. (2019). How Do Industrialization And Trade Openness Influence Energy Intensity? Evidence From A Path Model In Case Of Bangladesh. Energy Policy, www.elsevier.com/locate/enpol, https://doi.org/10.1016/j.enpol.2019.110916.

Semancikova, J. (2016). Trade, Trade Openness and Macroeconomic Performance. Procedia - Social and Behavioral Sciences 220, Science Direct, 407 - 416. doi: 10.1016/j.sbspro.2016.05.515.

Statistical, Economic and Social Research and Training Centre for Islamic Countries (SESRIC). (2018). OIC Economic Outlook. Ankara: Publication Department of SESRIC.

Toarna, A., and Cojanu, V. (2015). The 2008 Crisis: Causes and Future Direction for the Academic Research. Procedia Economics and Finance, 27(15), 385-393. https://doi.org/10.1016/S2212-5671(15)01010-2. 
Uz, I. (2010). Determinants of Current Account: Relation between Internal and External Balances in Turkey. Applied Econometrics and International Development, 10-2, 115-126.

Walter, J., Baek, J. and Koo, W. W. (2012). International Trade and Macroeconomic Dynamics: The Case of U.S. Bilateral Trade with G-7 Countries. Research in Economics, http://dx.doi.org/10.1016/j.rie.2012.06.003. 